\title{
Literasi Informasi Penyuluh Pertanian di Kabupaten Cianjur
}

\section{Information Literacy among Extension Workers in Cianjur Regency}

\author{
Rasmira $^{1}$, Djuara P. Lubis ${ }^{2}$, Dyah Gandasari ${ }^{1}$ \\ ${ }^{1}$ Politeknik Pembangunan Pertanian, Bogor \\ ${ }^{2}$ Departemen Sains Komunikasi dan Pengembangan Masyarakat, Institut Pertanian Bogor
}

\begin{abstract}
In the information overload, agricultural extension agents as agents of agricultural development need to have information literacy skills because most of their main tasks and functions are related to the activities of collecting, processing and disseminating agricultural information. This study aims to 1) identify information literacy among extension workers in Cianjur Regency2) analyze the factors that are related to information literacy among extension workers in Cianjur Regency. The study sample was 80 extension workers in Cianjur Regency. The method of analysis uses descriptive statistics and inferential statistics using Spearman Rank correlation to analyze relationships between variables. The results showed that the information literacy level of agricultural extension workers was classified as middle especially in storing and retrieving information, using information effectively and ethically, and communicating knowledge. Extension agents have a high ability in terms of recognizing the information needed, finding and evaluating it. Two factors that are significantly related to information literacy are characteristics of extension agents (age, formal education level, working life) and accessibility of communication media (ease of access and variety of media uses).
\end{abstract}

Key words: agriculture extension, information literacy

\begin{abstract}
Abstrak
Di tengah era banjir informasi, penyuluh pertanian sebagai agen pembangunan pertanian perlu memiliki kemampuan literasi informasi karena sebagian besar tugas pokok dan fungsi penyuluhan berkaitan dengan kegiatan pengumpulan, pengolahan dan penyebaran informasi pertanian. Penelitian ini bertujuan 1) mengidentifikasi literasi informasi penyuluh di Kabupaten Cianjur 2) menganalisis faktor-faktor yang berhubungan dengan literasi informasi penyuluh di Kabupaten Cianjur. Sampel penelitian adalah 80 orang penyuluh di Kabupaten Cianjur. Metode analisis menggunakan statistik deskriptif dan statistik inferensial menggunakan korelasi Rank Spearman untuk melihat hubungan antar peubah. Hasil penelitian menunjukkan bahwa tingkat literasi informasi penyuluh pertanian tergolong sedang dalam menyimpan dan menemukan kembali informasi, menggunakan informasi secara efektif dan etis, dan mengkomunikasikan pengetahuan. Penyuluh memiliki kemampuan yang tinggi dalam hal merumuskan informasi yang dibutuhkan, mencari dan mengevaluasinya. Dua faktor yang berhubungan nyata dengan literasi informasi adalah karakteristik penyuluh (umur, tingkat pendidikan formal, masa kerja) dan aksesibilitas media komunikasi (kemudahan akses dan ragam penggunaan media).
\end{abstract}

Kata Kunci: penyuluh pertanian, literasi informasi

\footnotetext{
${ }^{1}$ Korespondensi penulis

E-mail:rararantau@gmail.com
} 


\section{Pendahuluan}

Pembangunan pertanian tidak terlepas dari peran strategis penyuluh pertanian sebagai bagian dari fungsi sistem yang mengupayakan kemudahan akses pelaku utama dan pelaku usaha ke sumber informasi, teknologi, dan sumber daya lainnya agar mereka dapat mengembangkan usahanya (UU Nomor 16 Tahun 2006 tentang Sistem PenyuluhanPertanian, Perikanan, dan Kehutanan). Penyuluh pertanian berperan dalam menyebarkan informasi yang berkaitan dengan upaya perbaikan cara-cara bertani dan berusahatani demi tercapainya peningkatan produktivitas, pendapatan petani dan perbaikan kesejahteraan masyarakat atau keluarga (Mardikanto 2010).

Peranan penyuluh pertanian menurut van den Ban dan Hawkins (1996) adalah membantu petani membentuk pendapat yang sehat dan membuat keputusan yang baik dengan cara berkomunikasi dan memberikan informasi yang mereka perlukan. Christoplos(2010) menyatakan bahwa penyuluh sebagai sebuah sistem yang memfasilitasi akses bagi petani, kelompok tani, dan pelaku lainnya kepada pengetahuan, informasi dan teknologi, menghubungkan petani dengan pihak penelitian, pendidikan, agribisnis, pemasaran dan institusi terkait lainnya, dan membantu mengembangkan teknik, organisasi dan kemampuan manajemen secara terampil dan praktis. Pendapatpendapat tersebuttersebut memperlihatkan bahwa penyuluh pertanian dengan informasi merupakan dua hal yang tidak dapat dipisahkan terkait dengan peran penyuluh dalam kegiatan mengumpulkan, mengolah dan mendesimenasikan informasi pertanian dari dan untuk petani.

Menurut Leeuwis (2009) ada sejumlah media komunikasi sebagai alat untuk membantu menggabungkan saluran komunikasi dan informasi yang berbeda dalam transportasi sinyal teks, visual, audio, sentuhan dan atau penciuman yang terdiri atas media massa konvensional, media interpersonal, dan media hibrida. Media massa konvensional misalnya koran, jurnal pertanian, leaflet, radio dan televisi. Dengan media intepersonal pertukaran pesan bersifat langsung, melibatkan kehadiran fisik, tatap muka, misalnya pertemuan kelompok dan pertemuan diantara dua orang. Media hibrida mengombinasikan potensi yang ditawarkan oleh media massa dan komunikasi interpersonal. Teknologi internet dan CD ROM misalnya, merupakan media secara potensial mencapai audiens yang luas, yang membiarkan aktivitas antara penerima dan pengirim sampai taraf tertentu.

Komputer dan internet boleh jadi tidak akan dapat diakses oleh masyarakat pedesaan, tetapi petani akan terlayani oleh para penyuluh pertanian yang menyediakan informasi (dari internet) kepada masyarakat pedesaaan (Rivera \& Qamar 2003). Sejalan dengan perkembangan ilmu pengetahuan dan teknologi bidang pertanian, penyebaran informasi melalui media cetak dan elektronis semakin meningkat. Kedua media ini sangat potensial bagi penyuluh dan petani sebagai media untuk memperoleh informasi pertanian. Namun ketersediaan media informasi tersebut belum menjamin informasi digunakan oleh penyuluh padahal peningkatan layanan informasi terhadap petani akan mempercepat proses transfer teknologi yang telah dihasilkan oleh lembaga-lembaga penelitian (Andriaty \& Setyorini 2012).

Era informasi melahirkan banyak pilihan media belajar yang dapat digunakan untuk meningkatkan kemampuan, namun kenyataannya kompetensi penyuluh masih rendah (Anwas 2009). Hasil penelitian Veronice (2013) menyatakan bahwa tingkat pemanfaatan teknologi informasi dan komunikasi oleh penyuluh THL-TBPP sangat tinggi terutama dalam pemanfaatan komputer, internet dan handphone, sebaliknya pada penyuluh PNS tergolong 
rendah terutama pada pemanfaatan komputer dan internet. Sementara hasil penelitian Wijaya (2015) menemukan bahwa Kemampuan penyuluh dalam pemanfaatan Cyber Extension akan didukung oleh kelancaran penyuluh dalam menjalankan tahapan pencarian informasi. Elian (2015) menemukan bahwa terjadi ketimpangan pada pemanfaatan informasi pertanian oleh penyuluh, sebab informasi yang diperoleh belum pada tahap disebarkan ke petani. Lebih dari separuh penyuluh hanya membagikannya ke sesama penyuluh, bahkan masih ada penyuluh yang memanfaatkan informasi tersebut untuk disimpan pribadi.

Berbagai hasil penelitian menunjukkan bahwa penyuluh pertanian merupakan sumber utama petani dalam memperoleh informasi pertanian(Tamba\& Sarma 2007, Ardu 2007, Andriaty et al. 2011, Andriaty \& Setyorini 2012, Hernanda et al. 2015). Tetapi perkembangan TIK yang begitu pesat terutama munculnya internet dan media sosial menyebabkan informasi menjadi sangat banyak (information overload) dalam kualitas dan kuantitas yang berbeda danuntuk mengatasinya diperlukan literasi informasi (Bawden \& Robinson 2009). Penyuluh perlu memiliki keterampilan literasi informasi dalam menjalankan tugas penyuluhan karena literasi informasi dan teknologi merupakan keterampilan dasar abad 21 yang diakui dan diterima secara luas untuk semua jenis pekerjaan dari level bawah hingga eksekutif puncak (Eisenberg 2008).

Literasi informasi disebut juga melek informasi, yakni kesadaran akan kebutuhan informasi seseorang, mengidentifikasi, mengakses secara efektif efisien, mengevaluasi, dan menggabungkan informasi secara legal ke dalam pengetahuan dan mengomunikasikan pengetahuan itu (Lasa 2009). Literasi informasi dipandang sebagai elemen pusat dalam berbagai kompetensi komunikasi orang dewasa, selain kompetensi berpikir, kemampuan komunikasi lisan, kemampuan menggunakan media dan teknologi informasi dan komunikasi (Catts \& Lau 2008).

Gorman (2003) menyatakan literasi informasi sebagai penyokong utama pembangunan berkelanjutan dan pembangunan karakter karena mengajarkan cara berpikir kritis dalam memahami, mengartikan dan menggunakan informasi yang dibutuhkan bagi pembangunan. Menurut Eisenberg (2008) literasi informasi merupakan seperangkat keterampilan dan pengetahuan yang tidak hanya membantu kita untuk menemukan, mengevaluasi dan menggunakan informasi yang dibutuhkan, tetapi juga hal yang sangat penting yakni mengajak kita untuk menyaring informasi yang tidak dibutuhkan. Sementara menurut Horton (2007) literasi informasi berhubungan dengan konsep belajar sepanjang hayat (lifelong learning) karena dimotivasi dan diarahkan oleh diri sendiri, pemberdayaan diri sendiri, dan menggerakkan diri sendiri.

Literasi informasi juga merupakan kunci keberhasilan penyuluh dalam menyampaikan informasi yang telah tersaring kepada petani dan memuaskan kebutuhan informasi mereka.Informasi yang telah tersaring meningkatkan kepercayaan petani terhadap penyuluh sebagai sumberinformasi yang dapat dipercaya. Gonzalez dan Israel (2010) menunjukkan bahwa preferensi klien dalam memilih saluran komunikasi (media massa atau media interpersonal) ditentukan oleh manfaat yang diperoleh, biaya yang dikeluarkan dan tingkat kepercayaan terhadap sumbe rinformasi.

Besarnya tantangan yang dihadapi oleh penyuluh di tengah membanjirnya informasi dan terjadinya kesenjangan informasi dan juga kesenjangan digital baik secara global maupun individual menuntut diperlukannya penelitian yang lebih mendalam dan komprehensif terhadap 
literasi informasi penyuluh pertanian. Berdasarkan situasi dan kondisi penyuluhan saat ini, maka dipilihlah Kabupaten Cianjur sebagai lokasi penelitian karena Kabupaten Cianjur merupakan salah satu daerah dengan potensi pengembangan agribisnis di Jawa Barat terutama tanaman pangan dan komoditas hortikultura sehingga peran penyuluh dan kecakapannya dalam mencari dan menyajikan informasi yang tersaring dan berguna bagi petani menjadi kompetensi penting yang harus dimiliki.

Menurut hasil penelitian Purwatiningsih et al. (2018) pemanfaatan internet oleh penyuluh di kabupaten Cianjur tergolong sedang, artinya penyuluh kadang-kadang memanfaatkan internet dalam melaksanakan kegiatan baik dalam hal penyusunan laporan, pembuatan rancangan metode penyuluhan, penyusunan programa, dan pembuatan materi penyuluhan tersebut. Sehingga perlu kajian lebih lanjut yang berhubungan dengan tingkat pemanfaatan internet untuk kegiatan penyuluhan melalui fasilitasi hybrid media. Tetapi selain hybrid media, penelitian ini juga melihat pemanfaatan media massa konvensional dan media interpersonal oleh penyuluhdalam mencari informasi. Sesuai dengan permasalahan yang telah diuraikan tersebut, maka tujuan penelitian ini adalah mengidentifikasi literasi informasi penyuluh pertanian di Kabupaten Cianjur dan menganalisis faktor-faktor yang berhubungan dengan literasi informasi penyuluh pertanian di Kabupaten Cianjur.

\section{Metode Penelitian}

Penelitian didesain sebagai penelitian survei yang bersifat deskriptif korelasional dengan memaparkan data yang diperoleh dari responden melalui kuesioner dan wawancara. Penelitian dilakukan di Kabupaten Cianjur. Jumlah sampel ditentukan mengikuti ketentuan Slovin dengan batas toleransi 5 persen, sehingga dari 100 populasi didapat 80 sampel. Pengambilan data dilaksanakan pada bulan
April-Juni 2018. Peubah yang dinilai adalah karakteristik individu penyuluh, aksesibilitas media komunikasi, dan literasi informasi.

Data yang digunakan dalam penelitian meliputi data primer dan data sekunder. Data primer berupa peubah utama yang ingin diteliti diperoleh secara langsung dengan mewawancarai responden menggunakan kuesioner yang disediakan. Wawancara mendalam dan diskusi kelompok terarah dengan beberapa responden dilakukan untuk mendapatkan data kualitatif sebagai penguat data kuantitatif. Data sekunder yang terkait dengan fokus penelitian diperoleh dari pencatatan data instansi terkait.

Analisis data secara statistik deskriptif menggunakan frekuensi dan persentase, serta statistik inferensial menggunakan uji korelasi Rank Spearman untuk melihat tingkat keeratan hubungan antar peubah dengan bantuan program SPSS versi 22. Karakteristik individu, aksesibilitas media komunikasi, dan tingkat literasi informasi penyuluh diolah dengan ditabulasikan dan dijelaskan secara kualitatif.

\section{Hasil dan Pembahasan}

\section{Literasi Informasi Penyuluh Pertanian}

Peubah literasi informasi penyuluh pertanian mengacu pada komponen literasi informasi yang dikemukakan oleh Catts dan Lau (2008) meliputi: mengenali kebutuhan informasi, mencari dan mengevaluasi informasi, menyimpan dan menemukan kembali informasi, menggunakan informasi secara efektif dan etis, dan menggunakan informasi untuk menciptakan dan mengkomunikasikan pengetahuan. Jumlahdan persentase literasi informasi responden di lokasi penelitian terdapat pada Tabel 1. Pada tahapan mengenali kebutuhan informasi responden mempunyai kemampuan yang tinggi dengan persentase 55\% (Tabel 1). Langkah-langkah yang dilakukan responden dalam mengenali 
Tabel 1. Jumlah dan Persentase Literasi Informasi Penyuluh Pertanian Kabupaten Cianjur (2018)

\begin{tabular}{|c|c|c|c|c|}
\hline No & Literasi Informasi & Kategori & $\begin{array}{l}\text { Jumlah } \\
\text { (orang) }\end{array}$ & Persentase (\%) \\
\hline \multirow[t]{3}{*}{1} & Mengenali kebutuhan informasi & Rendah & 11 & 13.75 \\
\hline & & Sedang & 25 & 31.25 \\
\hline & & Tinggi & 44 & 55.00 \\
\hline \multirow[t]{3}{*}{2} & Mencari dan mengevaluasi informasi & Rendah & 13 & 16.25 \\
\hline & & Sedang & 33 & 41.25 \\
\hline & & Tinggi & 34 & 42.50 \\
\hline \multirow[t]{3}{*}{3} & Menyimpan dan menemukan kembali informasi & Rendah & 16 & 20.00 \\
\hline & & Sedang & 53 & 66.25 \\
\hline & & Tinggi & 11 & 13.75 \\
\hline \multirow[t]{3}{*}{4} & Menggunakan informasi secara efektif dan etis & Rendah & 1 & 1.25 \\
\hline & & Sedang & 51 & 63.75 \\
\hline & & Tinggi & 28 & 35.00 \\
\hline \multirow[t]{3}{*}{5} & Mengkomunikasikan pengetahuan & Rendah & 17 & 21.25 \\
\hline & & Sedang & 57 & 71.25 \\
\hline & & Tinggi & 6 & 7.5 .00 \\
\hline
\end{tabular}

kebutuhan informasi adalah merumuskan terlebih dahulu informasi apa yang akan dicari. Penyuluh menganalisis kebutuhan informasi dengan cara berdiskusi dengan petani dan rekan sejawat. Diehm dan Lupton (2012) menjelaskan tiga strategi utama untuk belajar literasi informasi yaitu belajar dengan melakukan (learning by doing), belajar dengan cara uji coba (learning by trial and error); dan belajar dengan cara berinteraksi dengan orang lain (learning by interacting with other people).

Pada tahapan menemukan dan mengevaluasi informasi kemampuan penyuluh tergolong tinggi dengan persentase $42.50 \%$ (Tabel 1). Ketika mencari informasi, penyuluh lebih menyukai informasi dalam bentuk elektronik dan tercetak. Sebagian besar penyuluh mencari informasi melalui internet. Google merupakan mesin pencari yang banyak dipakai daripada mesin pencari yang lain. Laman yang sering dikunjungi adalah laman Kementerian Pertanian (http//www.pertanian.go.id). Media yang paling banyak digunakan untuk mengakses internet adalah telepon pintar (smartphone). Hal ini sesuai dengan apa yang dikemukakan oleh Aker (2011) bahwa telepon pintar bisa meningkatkan akses dan penggunaan informasi mengenai teknologi pertanian, dan secara potensial meningkatkan pembelajaran. Informasi yang telah ditemukan dievaluasi oleh penyuluh dengan cara membandingkan dengan penemuan/pengetahuan baru serta menanyakan kepada ahli. Hal ini dilakukan untuk memastikan kredibilitas dari informasi yang ditemukan. Hal ini sesuai dengan apa yang ditemukan oleh Thiga dan Ndungu (2015) bahwa sebagian besar penyuluh mengevaluasi informasi untuk kejelasan akurasi, relevansi dan kredibilitas kualitas informasi.

Pada tahapan menyimpan dan menemukan kembali informasi kemampuan penyuluh tergolong sedang dengan persentasae $66.25 \%$ (Tabel 1). Sebagian besar penyuluh menyimpan informasi yang ditemukan di komputer dalam bentuk folder-folder agar mudah ditemukan kembali. Namun ada juga penyuluh yang hanya mengambil intisari dari informasi yang ditemukan untuk dijadikan bentuk baru tanpa menyimpan sumber informasi tersebut. Studi Thiga dan Ndungu (2015) menemukan bahwa sebagian besar penyuluh tidak menyimpan salinan informasi sebagai pengetahuan baru. 
Jurnal Penyuluhan, September 2019, Vol. 15 No. 2

Pada tahapan menggunakan informasi secara efektif dan etis kemampuan penyuluh tergolong sedang (Tabel 1). Sebagian besar penyuluh memiliki kemampuan yang sedang dalam memahami dan menganalisis informasi yang ditemukan. Menurut penyuluh informasi yang ditemukan relevan dengan kebutuhan informasi mereka dalam menjawab permasalahan di lapangan karena mereka telah memilih berbagai sumber informasi yang dianggap bisa menjawab permasalahan mereka dan petani. Penggunaan informasi secara etis salah satunya dilakukan oleh penyuluh dengan cara mencantumkan sumber informasi yang diambil dari karya orang lain agar tidak terjadi plagiat. Dalam menjaga etika profesi penyuluh menyaring antara informasi yang boleh disebarkan dengan informasi yang tidak boleh disebarkan karena salah satu prinsip yang perlu dipegang teguh oleh penyuluh adalah informasi yang disebarkan harus mengalami penelitian dan sudah resmi dikeluarkan oleh lembaga yang berwenang.

Kemampuan penyuluh dalam menggunakan informasi untuk menciptakan dan mengkomunikasikan pengetahuan tergolong sedang (Tabel 1). Langkah yang diambil dalam mengkomunikasikan pengetahuan adalah memilih media yang paling tepat untuk mengkomunikasikannya atau memilih aplikasi teknologi informasi. Media tersebut dibuat dengan bahasa yang mudah dimengerti oleh petani. Dalam rangka mengkomunikasikan pengetahuan secara tertulis hampir sebagian besar penyuluh tidak memiliki karya tulis ilmiah maupun karya tulis populer. Walaupun ada beberapa penyuluh yang menulis buku, artikel, jurnal penelitian atau menulis populer di media sosial tetapi jumlahnya sangat sedikit. Kurangnya penyuluh dalam membuat karya tulis diakui karena padatnya jam kerja dan kekurangan waktu untuk menulis. Hal ini sesuai dengan studi Rufaidah (2013) yang menyatakan kompetensi literasi informasi pustakawan dan pengelola perpustakaan lingkup Kementerian Pertanian perlu ditingkatkan terutama kemampuan dalam mengevaluasi, memanfaatkan dan mengkomunikasikan informasi yang diperoleh dalam bentuk karya tulis yang dipublikasikan.

\section{Faktor-faktor yang Berhubungan dengan Literasi Informasi Penyuluh}

Dalam penelitian ini faktor-faktor yang diduga berhubungan nyata dengan literasi informasi penyuluh adalah karakteristik individu penyuluh dan aksesibilitas media komunikasi oleh penyuluh. Yang (2011) menunjukkan bahwa penentu dari literasi informasi adalah atribut individu, infrastruktur teknologi informasi, sumber daya manusia, teknologi produksi dan manajemen, dan kebijakan nasional informasi, hukum dan etika. Menurut Veronice (2013) Faktor karakteristik penyuluh memiliki hubungan sangat nyata dengan tingkat pemanfaatan TIK, khususnya umur, masa kerja. Untuk melihat hubungan masingmasing suppeubah digunakan analisis krelasi Rank Spearman.

\section{Karateristik Penyuluh}

Karakteristik penyuluh pertanian adalah ciriciri atau sifat yang ada dalam diri individu penyuluh pertanian yang langsung dapat diamati atau dibaca dari biodata dan berkenaan dengan atribut yang menjadikan orang berbeda dari orang lain meliputi usia, pendidikan formal, pendidikan nonformal, masa kerja, kepemilikan media Teknologi Informasi dan Komunikasi (TIK).

Karakteristik penyuluh di lokasi penelitian secara singkat dijelaskan dalam Tabel 2. Dari Tabel 2 dapat diketahui bahwa sebagian besar responden berusia muda hingga dewasa (23-46 tahun). Usia penyuluh rata-rata masih muda karena adanya program pengadaan Tenaga Harian Lepas tenaga Bantu penyuluh pertanian (THL TBPP). Penyuluh yang berstatus sebagai THL lebih banyak daripada penyuluh PNS. 
Tabel 2. Karakteristik Penyuluh Pertanian Kabupaten Cianjur Tahun 2018

\begin{tabular}{|c|c|c|c|c|}
\hline No & Profil penyuluh & Kategori & Jumlah (orang) & Persentase (\%) \\
\hline 1 & Usia (tahun) & $\begin{array}{l}\text { Muda (23-34 tahun) } \\
\text { Dewasa (35-46 tahun) } \\
\text { Tua (47-59 tahun) }\end{array}$ & $\begin{array}{l}30 \\
31 \\
19\end{array}$ & $\begin{array}{l}37.50 \\
38.75 \\
23.75\end{array}$ \\
\hline 2 & Tingkat Pendidikan formal & $\begin{array}{l}\text { SMA } \\
\text { Diploma } \\
\text { Sarjana }\end{array}$ & $\begin{array}{l}13 \\
13 \\
54\end{array}$ & $\begin{array}{l}16.30 \\
16.30 \\
67.50\end{array}$ \\
\hline 3 & Tingkat pendidikan nonformal & $\begin{array}{l}\text { Rendah (0-2 kali) } \\
\text { Sedang (3-5 kali) } \\
\text { Tinggi (6-7 kali) }\end{array}$ & $\begin{array}{l}56 \\
19 \\
5\end{array}$ & $\begin{array}{l}70.00 \\
23.75 \\
6.25\end{array}$ \\
\hline 4 & Masa kerja & $\begin{array}{l}\text { Baru (3-10 tahun) } \\
\text { Sedang (11-12 tahun) } \\
\text { Lama (27-37 tahun) }\end{array}$ & $\begin{array}{l}62 \\
7 \\
11\end{array}$ & $\begin{array}{l}77.50 \\
8.75 \\
13.75\end{array}$ \\
\hline 5 & Kepemilikan media TIK & $\begin{array}{l}\text { Rendah (1-2 unit) } \\
\text { Sedang (3-4 unit) } \\
\text { Tinggi (5-7 unit) }\end{array}$ & $\begin{array}{l}30 \\
46 \\
4\end{array}$ & $\begin{array}{l}37.50 \\
5.00 \\
7.50\end{array}$ \\
\hline
\end{tabular}

Sebagian besar penyuluh telah menempuh pendidikan sarjana, sebagian yang lain merupakan lulusan diploma dan SMA. Hal ini menunjukkan bahwa penyuluh pertanian di lokasi penelitian telah memiliki tingkat pendidikan formal yang tinggi, tetapi untuk pendidikan nonformal masih sangat rendah. Rendahnya jam pelatihan karena kurangnya kesempatan dari dinas terkait dalam rangka pengembangan kapasitas penyuluh. Masa kerja penyuluh tergolong baru berkisar antara 3 hingga 10 tahun bekerja sebagai penyuluh pertanian dengan persentase $77.50 \%$. Hal ini menunjukkan ada jarak masa kerja yang cukup jauh antara penyuluh senior dengan penyuluh muda karena tidak adanya pengangkatan penyuluh pertanian dalam waktu yang cukup lama. Rata-rata penyuluh memiliki 3-4 unit media TIK, diantaranya telepon seluler tanpa internet, telepon pintar (smartphone), laptop, dan komputer. Seluruh responden membeli sendiri telepon seluler dan smartphone, beberapa menggunakan laptop atau komputer milik kantor. Selebihnya responden memiliki TIK secara mandiri termasuk pulsa internet untuk menelusur informasi karena di kantor tempat penyuluh bekerja tidak tersedia layanan internet.

\section{Aksesibilitas Media Komunikasi}

Aksesibilitas adalah hal dapat dijadikan akses, hal dapat dikaitkan, keterkaitan. Aksesibilitas penyuluh terhadap media komunikasi adalah kemampuan interaksi penyuluh dengan berbagai saluran komunikasi, baik melalui media massa konvensional, media interpersonal maupun melalui media hybrid/internet. Aksesibilitas terhadap media komunikasi pertanian dilihat dari kemudahan akses terhadap media komunikasi dan ragam penggunaan media komunikasi, secara singkat terdapat pada Tabel 3. Kemudahan untuk mengakses media komunikasi di lokasi penelitian termasuk tinggi (Tabel 3). Media yang sangat mudah diakses adalah internetdan media interpersonal. Sebagian besar responden mengakses internet melalui smartphone. Jika pun mereka mengakses internet dari laptop tetapi jaringannya berasal dari hotspot pribadi yang ditambatkan dari handphone (tethering). Selain internet, media komunikasi yang juga sangat mudah diakses adalah media interpersonal. Media interpersonal terjalin dari komunikasi interpersonal antara penyuluh dengan petani, penyuluh dengan sesama penyuluh, dan penyuluh dengan lembaga. 
Jurnal Penyuluhan, September 2019, Vol. 15 No. 2

Tabel 3. Aksesibilitas Media Komunikasi oleh Penyuluh Pertanian di Kabupaten Cianjur Tahun 2018

\begin{tabular}{llrrr}
\hline No & Aksesibilitas Media & Kategori & Jumlah (orang) & Persentase (\%) \\
\hline 1 & Kemudahan akses media komunikasi & Rendah & 6 & 7.50 \\
& & Sedang & 33 & 41.25 \\
& & Tinggi & 41 & 51.25 \\
2 & Ragam penggunaan media & Rendah & 31 & 38.75 \\
& komunikasi & Sedang & 32 & 40.00 \\
& & Tinggi & 17 & 21.25 \\
\hline
\end{tabular}

Data di lapangan menunjukkan bahwa kemudahan dalam mengakses media interpersonal sangat dibantu oleh adanya telepon seluler sehingga komunikasi atau membuat rencana pertemuan semakin mudah dan hemat waktu. WhatsApp merupakan aplikasi komunikasi yang banyak dipakai oleh penyuluh dalam berkomunikasi. Media massa konvensional termasuk cukup mudah diakses terutama media berbentuk cetak karena jumlahnya yang terbatas dan tidak semua penyuluh bisa mendapatkan. Radio merupakan media yang sangat sedikit diakses oleh penyuluh. Menurut Catts dan Lau (2008) literasi informasi adalah seperangkat keterampilan yang memungkinkan seseorang untuk mendapatkan keuntungan dari beragamnya pengetahuan yang didapatkan dari sumber oral, tercetak dan bentuk elektronik.

Dari Tabel 3 dapat diketahui bahwa ragam penggunaan media oleh penyuluh berada pada kategori sedang dengan persentase $40 \%$. Dalam memenuhi kebutuhan informasi pertanian, media komunikasi yang paling banyak digunakan oleh penyuluh adalah media interpersonal yang terjadi melalui komunikasi interpersonal dengan rekan kerja, penyuluh senior, lembaga, dan juga petani. Informasi yang berasal dari ahli dan lembaga dianggap penyuluh lebih valid dan kredibel. Berbagi pengetahuan dengan orang lain adalah bagian dari literasi informasi sebagaimana yang kemukakan oleh Holma dan Pakalna (2015) bahwa seseorang sering menjadikan orang lain sebagai sumber informasinya hal ini memperlihatkan bahwa modal sosial memiliki peranan penting dalam mendapatkan informasi. Salah satu manfaat dari modal sosial adalah terjadinya pertukaran dan berbagi informasi. Efektifitas pertukaran informasi tergantung pada literasi informasi seseorang. Setelah media interpersonal, internet menjadi media komunikasi yang banyak digunakan oleh penyuluh dalam memenuhi kebutuhan informasi pertanian.

Rata-rata penyuluh mengakses internet 4 jam dalam sehari. Laman Kementerian Pertanian paling banyak dibuka karena kredibilitas sumbernya, selain itu penyuluh juga membuka blog, laman lembaga penelitian dan perguruan tinggi untuk mencari informasi. Internet tidak hanya digunakan untuk mencari informasi tetapi juga mengakses media sosial sebagai media komunikasi dan informasi dengan rekan dan juga sebagai sarana hiburan penyuluh. Hal ini sebagaimana diutarakan Leeuwis (2009) bahwa internetmemiliki aplikasi luas, dapat melayani tujuan yang berbeda-beda, dan banyak terkait dengan intervensi komunikatif dalam berbagai bidang kemasyarakatan, termasuk pertanian dan manajemen sumber daya.

Media yang paling sedikit digunakan oleh penyuluh dalam mencari informasi adalah media massa konvensional terutama berbentuk cetak. 
Tabel 4. Koefesien Korelasi Karakteristik Penyuluh dan Aksesibilitas Media Komunikasi dengan Literasi Informasi Penyuluh Pertanian di Kabupaten Cianjur Tahun 2018

\begin{tabular}{lcrrrr}
\hline Subpeubah & $\begin{array}{c}\text { Menya } \\
\text { dari } \\
\text { kebutu } \\
\text { han } \\
\text { informasi }\end{array}$ & $\begin{array}{c}\text { Mencari dan } \\
\text { mengeva } \\
\text { luasi } \\
\text { informasi }\end{array}$ & $\begin{array}{c}\text { Menyim } \\
\text { pan dan } \\
\text { menemu } \\
\text { kan } \\
\text { informasi }\end{array}$ & $\begin{array}{c}\text { Menggu } \\
\text { nakan } \\
\text { informasi }\end{array}$ & $\begin{array}{c}\text { Mengkomunika } \\
\text { sikan pengeta } \\
\text { huan }\end{array}$ \\
\hline Usia (X1.1) & $-0.273^{*}$ & $-0.244^{*}$ & -0.157 & -0.028 & -0.122 \\
Pendidikan formal (X1.2) & 0.116 & 0.183 & 0.056 & $0.319^{* *}$ & $0.295^{* *}$ \\
Pendidikan Nonformal (X1.3) & 0.095 & -0.059 & 0.071 & 0.096 & 0.154 \\
Masa kerja (X1.4) & $-0.254^{*}$ & -0.134 & -0.090 & -0.089 & -0.132 \\
Kepemilikan Media TIK (X1.5) & 0.133 & 0.147 & 0.026 & 0.172 & 0.077 \\
Kemudahan akses media (X2.1) & $0.443^{* *}$ & $0.348^{* *}$ & 0.201 & 0.151 & $0.316^{* *}$ \\
Ragam penggunaan media (X2.2) & 0.206 & $0.402^{* *}$ & $0.323^{* *}$ & $0.358^{* *}$ & $0.289^{* *}$ \\
\hline
\end{tabular}

Keterangan $*=$ berhubungan nyata pada taraf $0.05 * *=$ berhubungan sangat nyata pada taraf 0.01

Menurut penyuluh media cetak tidak praktis karena tidak bisa disalin atau dirubah secara elektronik dan kurang variatif dibanding internet. Hal ini sesuai dengan apa yang ditemukan oleh Anwas (2010) bahwa pemanfaatan media massa rendah terutama dalam pemanfaatan koran, buku, dan radio. Pemanfaatan majalah dalam katagori sedang, sedangkan televisi meskipun pemanfaatannya tinggi tetapi subtansinya kurang sesuai dengan kebutuhan penyuluhan.

\section{Hubungan antara Karakteristik Penyuluh dan Aksesibilitas Media Komunikasi dengan Literasi Informasi}

Hubungan antara karakteristik penyuluh dan aksesibilitas media komunikasi dengan literasi informasi dianalisis dengan menggunakan analisis korelasi Rank Spearman. Koefesien korelasi dari setiap peubah terdapat pada Tabel 4.

Dari Tabel 4 dapat diketahui karakteristik penyuluh yang berhubungan nyata dengan literasi informasi adalah usia, tingkat pendidikan formal dan masa kerja. Hubungan antara usia dan literasi informasi berkorelasi negatif dan nyata, yang menandakan semakin muda usia responden maka kemampuan dalam menyadari kebutuhan informasi, mencari dan mengevaluasi informasi akan semakin tinggi.
Sementara hubungan antara tingkat pendidikan formal dengan literasi informasi berkorelasi positif dan sangat nyata padatahapan menggunakan dan mengevaluasi informasi serta mengkomunikasikan pengetahuan. Hal ini menunjukkan bahwa semakin tinggi tingkat pendidikan formal maka kemampuan dalam menggunakan dan mengevaluasi informasi serta mengkomunikasikan pengetahuan juga akan semakin tinggi. Masa kerja berhubungan nyata dengan literasi informasi dan hubungan yang terjadi adalah negatif. Hal ini dapat diartikan bahwa semakin rendah masa kerja maka kemampuan respondendalam menyadari kebutuhan informasi juga semakin tinggi.

Hal ini sejalan dengan hasil penelitian Bakti (2012) bahwa semakin tinggi lama kerja seseorang maka semakin rendah literasi informasinya, Wahyuli (2008) menyatakan bahwa strata pendidikan mempengaruhi tingkat penguasaan literasi informasi, Mashroofa dan Senevirathne (2014) menyatakan bahwa usia, jenis kelamin, dan tingkat pendidikan mempengaruhi keterampilan literasi informasi.Peubah aksesibilitas media komunikasi berhubungan sangat nyata dengan literasi informasi meliputi kemudahan akses dan ragam penggunaan media. Kemudahan akses media komunikasi berhubungan sangat nyata dengan kemampuan 
menyadari kebutuhan informasi, mencari dan mengevaluasi informasi, dan mengkomunikasikan pengetahuan. Semakin mudah media komunikasi diakses maka kemampuan responden dalam menyadari kebutuhan informasi, mencari dan mengevaluasi informasi, dan mengkomunikasikan pengetahuan akan semakin tinggi.

Hasil studi Wijaya (2015) menemukan bahwa ketersediaan sarana akses dan biaya operasional berhubungan sangat nyata dengan tahapan pencarian informasi oleh penyuluh pertanian. Hasil survei literatur yang dilakukan oleh Wicaksono (2016) menemukan bahwa ketersediaan komputer dan jaringan internet, kebijakan, dan tugas yang dilakukan seharihari mempengaruhi literasi informasi.

Dari Tabel 4 dapat diketahui ragam penggunaan media komunikasi berhubungan sangat nyata dengan kemampuan mencari dan mengevaluasi informasi, menyimpan dan menemukan kembali informasi; menggunakan informasi secara efektif, dan mengkomunikasikan pengetahuan. Hubungan yang terjadi adalah positif dengan arti kata semakin beragam media komunikasi yang digunakan maka semakin tinggi pula kemampuan mencari dan mengevaluasi informasi, menyimpan dan menemukan kembali informasi, menggunakan informasi secara efektif, dan mengkomunikasikan pengetahuan. Catts dan Lau (2008) menyatakan bahwa seseorang menggunakan literasi informasi dalam memecahkan masalah dan keterampilan komunikasi sebagai bagian dari perangkat keterampilan yang diperlukan oleh orang dewasa untuk mencapai efektifitas dalam semua aspek kehidupan mereka. Manfaat literasi informasi sebagai kompetensi komunikasi orang dewasa berbeda dari kompetensi lain karena kompleksnya kapasitas literasi informasi dilihat dari perbedaan efektifitas penggunaan informasi, ketersediaan, dan akses terhadap informasi.

\section{Kesimpulan}

Tingkat literasi informasi penyuluh pertanian tergolong sedang terutama dalam menyimpan dan menemukan kembali informasi, menggunakan informasi secara efektif danetis, dan mengkomunikasikan pengetahuan. Penyuluh memiliki kemampuan yang tinggi dalam hal merumuskan informasi yang diperlukan, menemukan dan mengevaluasinya. Penyuluh melibatkan orang lain dalam menentukan kebutuhan informasi baik itu petani maupun rekan sejawat. Penyuluh mencari informasi dari berbagai sumber dan dalam berbagai bentuk. Informasi yang diapatkan dievaluasi dengan cara membandingkan dari berbagai sumber dan berdiskusi dengan ahli. Kemampuan mengkomunikasikan pengetahuan tergolong sedang. Penyuluh memilih media yang tepat dan mengaplikasikan teknologi dalam mengkomunikasikan karya kepada petani tetapi tulisan yang dihasilkan ataupun diunggah oleh penyuluh di media masih rendah. Faktor-faktor yang berhubungan nyata dengan literasi informasi penyuluh pertanian adalah karakteristik penyuluh meliputi usia, masa kerja, dan tingkat pendidikan formal; literasi informasi berhubungan sangat nyata dengan aksesibilitas media komunikasi meliputi kemudahan akses dan ragam penggunaan media. Hubungan antara usia dan masa kerja dengan literasi informasi berkorelasi negatif dan nyata, hubungan antara tingkat pendidikan formal dengan literasi informasi berkorelasi positif dan nyata, hubungan antara aksesibilitas media komunikasi dengan literasi informasi berkorelasi positif dan sangat nyata.

\section{Daftar Pustaka}

Aker JC. 2011. Dial “A” for Agriculture: a Review of Information and 
Communication Technologies for Agricultural Extension in Developing Countries. Agricultural Eonomics. 42(2011):631-647. DOI: 10.1111/j.15740862.2011.00545.x

Andriaty E, Setyorini E. 2012. Ketersediaan Sumber Informasi Teknologi Pertanian di Beberapa Kabupaten di Jawa. Jurnal Perpustakaan Pertanian 21(1): 30-35.

Andriaty E, Sankarto BS, Setyorini E. 2011. Kajian Kebutuhan Informasi Teknologi Pertanian di Beberapa Kabupaten di Jawa. Jurnal Perpustakaan Pertanian 20(2):54-61.

Anwas OM, Sumardjo, Asngari PS, Tjiptopranoto P. 2009. Faktor-Faktor yang Mempengaruhi Penyuluh dalam Pemanfaatan Media. Jurnal Komunikasi Pembangunan 7(2):68-81.

Anwas OM. 2010. Pengembangan Kompetensi Penyuluh Pertanian Berbasis Media Massa. Jurnal Pendidikan dan Kebudayaan 16(6):737-746.

Bakti LA. 2012. Hubungan Literasi Informasi dengan Publikasi Hasil Penelitian Peneliti di Pusat Penelitian Bioteknologi-LIPI. [tesis]. Depok (ID): Universitas Indonesia.

Bawden D, Robinson L. 2009. The Dark Side of Information: Overload, Anxiety and other Paradoxes and Pathologies. Journal of Information Science 35(2):180-19. DOI: $10.1177 / 0165551508095781$

Catts R, Lau J. 2008. Towards Information Literacy Indicators. Paris (FR): United Nations Educational, Scientific and Cultural Organization (UNESCO).

Christoplos I. 2010, Mobilizing the Potential of Rural and Agricultural Extension. Rome (IT): FAO. [internet][Dapat diunduh di: http://www.fao.org/docrep/012/i1444e/i1 444e0.pdf]

Diehm RA, Lupton M. 2012. Approaches to Learning Information Literacy: a phenomenographic study. The Journal of Academic Librarianship 38(4):217-225.

Eisenberg MB. 2008. Information Literacy: Essential Skills for the Information Age. DESIDOC Journal of Library \& Information Technology 28(2): 39-47.

Elian N, Lubis DP, Rangkuti PA. 2015. Penggunaan Internet dan Pemanfaatan Informasi Pertanian oleh Penyuluh Pertanian di Wilayah Barat Kabupaten Bogor. Jurnal Komunikasi Pembangunan 12(2):104-109.

Eppler MJ, Mengis J. 2004. The Concept of Information Overload. The Information Society 20(5): 325-344.

Gonzalez SG, Israel GD. 2010. The Influence of Type of Contact with Extension on Client Satisfaction [internet]. Dapat diunduh di: http:// www.joe.org/joe/2010february/a4.php

Gorman GE. 2003. Sustainable Development and Information Literacy: IFLA Priorities in Asia and Oceania. IFLA Journal2(4):288-294.

Hernanda TAP, Fatchiya A, Sarma M.. 2015. Tingkat Kinerja Penyuluh Pertanian diKabupaten Ogan Komering Ulu (OKU) Selatan. Jurnal Penyuluhan 11(1):79-90.

Holma B, Pakalna D. 2015. Information Literacy in Community Development. Research for Rural Development 1:271276.

Horton FW. 2008. Understanding Information Literacy: a primer. Paris (FR): United Nations Educational, Scientific and Cultural Organization (UNESCO).

Lasa HS.2009. Kamus Kepustakawanan Indonesia.Yogyakarta (ID): Pustaka Book Publisher

Leeuwis C. 2009. Komunikasi untuk Inovasi Pedesaan: berpikir kembali tentang penyuluhan pertanian. Yogyakarta (ID): Kanisius. 
Mardikanto T. 2010. Penyuluhan Pembangunan Pertanian. Surakarta (ID): Universitas Sebelas Maret.

Mashroofa MM, Senevirathne W. 2014. Influence of Information Literacy Skills in Accessing Agricultural Information: with special reference to paddy farmers of Ampara district, Sri Lanka. IFLA LYON 1-17.

Purwatiningsih NA, Fatchiya A, Mulyandari RSH. 2018. Pemanfaatan Internet dalam Meningkatkan Kinerja Penyuluh Pertanian di Kabupaten Cianjur. Jurnal Penyuluhan 14(1):79-91.

Rivera WM, Qamar MK. 2003. Agricultural Extension Development and The food Security Challenge. Food and Agricultural Organization of The United Nations. Rome [internet] [Dapat diunduh di

http://www.fao.org/docrep/006/Y5061E/ Y5061E00.HTM]

Rufaidah VW. 2013. Literasi Informasi Pustakawan/Pengelola Perpustakaan Lingkup Kementerian Pertanian. Jurnal Perpustakaan Pertanian 22(1):16-23.

Tamba M, Sarma M. 2007. Faktor-Faktor yang Mempengaruhi Kebutuhan Informasi Pertanian bagi Petani Sayuran di Provinsi Jawa Barat. Jurnal Penyuluhan 3(1):24-34.

Thiga MM, Ndungu S. 2015. Utilization of ICT for Agriculture: A Case Study of Kakamega County, Kenya. IST-Africa 2015 Conference Proceedings Paul Cunningham and Miriam Cunningham (Eds) IIMC International Information Management Corporation. [internet]Dapat diunduh di: www.ISTAfrica.org/Conference2015

Undang Undang Republik Indonesia Nomor 16 Tahun 2006 Tentang Sistem Penyuluhan Pertanian, Perikanan, dan Kehutanan.
Van den Ban AW, Hawkins HS. 1999. Penyuluhan Pertanian. Edisi ke-3. Yogyakarta (ID): Penerbit Kanisius.

Veronice. 2013. Pemanfaatan Teknologi Informasi dan Komunikasi Dalam Peningkatan Kompetensi Penyuluh. [tesis]. Sekolah Pascasarjana IPB. Bogor.

Wahyuli L. 2008. Keterampilan Instruktur Materi Information Literacy (IL): studi kasus Program Orientasi Belajar Mahasiswa (OBM) Universitas Indonesia. [Tesis]. Depok (ID): Universitas Indonesia.

Wicaksono A. 2016. Profil Literasi Informasi Pustakawan Indonesia. Berkala Ilmu Perpustakaan dan Informasi 7(1): 1-9.

Wijaya AS. 2015. Pemanfaatan Cyber Extension Sebagai Media Informasi oleh Penyuluh Pertanian di Kabupaten Bogor. [tesis]. Bogor (ID): Institut Pertanian Bogor.

Yang, F. 2011. Exploring the Information Literacy of Professionals in Safety Management. Safety Science 50(2): 294299. 